\title{
A GENDER AWARENESS HIDDEN CURRICULUM TO PROMOTE GENDER EQUALITY AT PRIMARY SCHOOLS IN INDONESIA
}

\author{
Meinarni s \\ Dosen UIN Malang
}

\begin{abstract}
Pengaruh pengarusutamaan gender membawa angin segar dalam sosialisasi program dan kegiatan pemberdayaan perempuan. Paling tidak, masyarakat luas sudah terbiasa mendengar istilas-istilah 'pemberdayaan perempuan', kesetaraan gender' dll dalam kehidupan sehari-hari. Namun demikian, perlu dilakukan upaya-upaya yang lebih sistematis dan membumi agar kesetaraan gender segera dapat direalisasikan. Dalam artikel ini, penulis memberikan argumen pentingnya merangsang kesadaran siswa untuk menyadari pentingnya kesetaraan gender melalui kegiatan belajar mengajar.
\end{abstract}

\section{Introduction}

Gender nowadays has become a very common topic of discussion among people in their daily conversations. This is probably one of the positive impacts of gender mainstreaming, a government program to socialize gender equality among decision makers (especially government officials) all over Indonesia. However ${ }^{1}$ indicates that the realization of gender equality is still far from what is expected. She further shows that some gender disparities can be easily found in many parts of our life as a result of misunderstanding the concept of gender and, more importantly, "the gap between cognitive (understanding the concept) and behavioral (applying the concept) levels". This may lead to the creation of a gender gap.

\footnotetext{
${ }^{1}$ Indraswari Gender Equality: Easy to Theorize Difficult to Apply, Opinion, The Jakarta Post, August 9. 2006.
} 
The fact that this gap happens on a world-wide scope in various levels of inequality is quite clear. A more grounded and practical effort is needed to address this issue. It is generally admitted that school is "the best place to start combating such inequality through gender-equitable curriculum and pedagogy". ${ }^{2}$ This need becomes more urgent in response to Millennium Development Goal (MDG) 3 by United Nation (UN) to promote gender equality and empower women. In educational settings, this goal is geared toward eliminating the gender gap in primary and secondary levels in 2005 and in all levels by 2015. From the National Plan of Action $2003 / 2015^{3}$, it is clearly stated that the Indonesia government has set up a nationally concerted effort to develop gender-based education through central and local policies as a way of eradicating gender disparity in Indonesia. In reality, however, only a few have been already done to apply this gender based curriculum. From this point of view, then, I should say integrating gender awareness into school curriculum at primary school level is extremely important.

To start with, this essay will provide definitions of key terms which are followed by displaying some facts which compel gender awareness at school. In the following sections, some arguments denying the importance of gender awareness hidden curriculum and shortcomings of these views will be elaborated which, then, is followed by the discussion of the benefits of applying a gender awareness hidden curriculum at school.

\footnotetext{
2 Aikman, Unterhalter, and Challender, The education MDGs: achieving gender equality through curriculum and pedagogy change, Gender and development vol.13 no.1 March. 2005

${ }^{3}$ Unesco, National Plan of Action Indonesia's Education for All. portal.unesco.org/education/en/evphp.URL_ID=22302\&URL_DO=DO_PRINTPAGE\&URL_SECTIO $\mathrm{N}=201 . h t m l-16 k .2003$.
} 


\section{Some Related Basic Concepts of Gender}

The concept of gender and sex is remarkably different. Sex is generally defined as a set of biological differences between man and women. These differences are innate and tend to be permanent. Gender, in contrast, refers to the socially constructed roles and relationships of women and men. Because these are learned, these may change over the time and vary within and between countries and cultures according to social, religious, historical and economic factors. These roles and responsibilities affect male's and female's participation and ability to reap the benefits of the development. The different roles and responsibilities may lead to a gender gap, which can possibly create some serious problems in our society.

The other important term is gender awareness. It is "a state of knowledge of the differences in roles and relations of women and men, which results in differences in power relation, statuses, privileges, and needs" ${ }^{4}$. Within this definition, however, gender disparities still exist. ${ }^{5}$ points out that certain people have already been aware of the importance of gender equality but can do nothing to solve some problems caused by the gender gap happening in front of them. Thus, in this paper, gender awareness refers to the readiness of people to actualize differences in roles and relations of women and men, which results in differences in terms of power relation, statuses, privileges and needs to promote gender equality in their surroundings. In this sense, as it is generally defined, gender equality refers to equivalent opportunities and outcomes for women and

\footnotetext{
${ }^{4}$ Unesco, SNDP, undated, 2003.

${ }^{5}$ Indraswari Gender Equality: Easy to Theorize, 2006.
} 
men, which involves the removal of discrimination and structural inequalities in access to resources, opportunities, and services as well as promotion of equal rights.

Why should we bother gender awareness at school? For one thing, it is indicated that gender discrimination is deeply rooted throughout education systems ${ }^{6}$. The very crystal clear proof is that textbooks, widely used at schools all over Indonesia, strengthen gender stereotypes by showing male creativity and citing male heroes more frequently. In addition, a higher number of girls drop out from school in Indonesia; six in ten were female ${ }^{7}$. It is shown that more females ranked 'getting married in early ages' higher than economic problem and motivation. Due to unequal practices, this gender gap at school still occurs even when the schools are available freely.

In more developed countries, this gender gap also exists although in a different version. ${ }^{8}$ found out that less than $17 \%$ girls in US were wiling to enroll in computer science classes. This percentage tends to decline when higher levels are involved. In other words, the more advanced the class, the smaller the proportion of females. ${ }^{9}$. This study, which involved the senior high school students, revealed that sexual harassment was found at school. He further illustrated that $80 \%$ of the students were harassed, $50 \%$ of them happened regularly while a large portion of the harassment happened in class. He also noted that $61 \%$ of the students under the study suffered from physical sexual harassment which also entailed other serious psychological problems.

In a broader sense, the gender gap causes deep-seated violence. A 2005 study of WHO uncovered that in 10 countries women tended to be subjected to physical abuse or

\footnotetext{
${ }^{6}$ Unesco, Education for All 2000 Assessment: Thematic studies (Girls Education), 2000.

${ }^{7}$ National Plan of Action, 2003.

${ }^{8}$ Guerard EB, 2005, Computer teachers learn gender awareness, eschool news online. www.eschoolnews.com/news. 2006.

9 An even more serious research finding in US was reported by Hadley, 2001.
} 
sexual harassments by their devoted partners ${ }^{10}$. Besides that, there are many more victims of Female Genital Mutilation (FGM), dowry murder, and honor killings in SubSaharan Africa, Africa, Bangladesh, Pakistan and India as a part of cultural practices. These gender disparities can be glaring major obstacles to gender equality ${ }^{11}$.

Within this frame, gender awareness is a keystone of gender equality which is crucial in eradicating gender disparities and practices that discriminate against girls and women in a wider society to nourish the development of social, political, and economical aspects. In fact, according to Aikman, Unterhalter, and Challender, this is one strategic way, recommended to be internationally applied, of achieving a genderequitable education. In a more practical way, providing gender awareness at school will not only help female maintain schooling but also potentially has given significant positive impacts to eliminate gender disparities ${ }^{12}$.

\section{Some Counter Arguments}

Despite the facts mentioned above, some people claim that integrating gender awareness at schools is not possible for several reasons. First of all, these people say that teacher has limited stocks of gender sensitive materials suitable with Indonesia context. For them, gender disparities emerge in certain forms in accordance with certain cultures. In other words, gender inequality is culture-bound. This argument, however, is only true for a very limited case. In fact, gender disparities are proved to be universal

\footnotetext{
${ }^{10}$ Unesco, 2006

${ }^{11}$ Unifem, Facts and figures on VAW.

www.unifem.org/gender_issues/violence_against_women/facts_figures.php?page2. 2006

${ }_{12}$ Green, et al., 2004; Risberg, Hamberg, and Johansson, 2003; Abrahams and Somerton, 2000.
} 
matters which do not essentially vary from one country to others ${ }^{13}$. Similarly, if we expect the very technical sources which are nationally applied by the government, this might be true as this involves very long procedures and processes. Indeed, we have a plethora of choices available everywhere, especially the electronic versions. The 'www.media-awareness.ca', for example, provides freely accessed excellent materials for gender awareness programs written in some internationally spoken languages. These materials are so practical that teacher can directly apply them to their class; simple adopting and adapting processes are only necessitated to adjust to students' individual needs which naturally happens in any case. In addition, the materials are well-founded and designed for different age levels. The wide range of topics makes it possible for any teacher to accommodate various problems of gender inequality and adapt to classes with different culture and values. Furthermore, there are many more research-based materials provided by international agents such as Gender Tipsheets by OECD, Beyond Access Resources published by Oxfam in collaboration with Institute of Education University of London.

People also claim that integrating gender awareness is not possible to do because of insufficient supports from the decision makers in regional and school levels. Some bureaucrats have already been able to detect the existence of gender disparity but they are not willing to take an action ${ }^{14}$. Or, it is further said, these decision makers do not have sufficient power to face their super ordinates who do not want to change the policies. This argument may have been true until recently. As a signatory of the Beijing Declaration in 1995, the government has placed gender equality the first priority among

\footnotetext{
${ }^{13}$ Kirk, J, Promoting a gender-just peace : the roles of women teachers in peace building and reconstruction, Gender and DevelopmentI vol.12 no 3 November. 2004

${ }^{14}$ Indraswari, Gender Equality: Easy to Theorize, 2006.
} 
other urgent national programs ${ }^{15}$. The Millennium Development Goal 3 mandated by UN convincingly provokes 'political pressures' to the government to set up more practical policies which reach school. These have been practically realized by both Ministry of National Education and Ministry of Women Empowerment by applying several programs to make sure that gender equality is guaranteed to happen at schools. An intensive collaboration among Women Studies Center of universities in Indonesia with local governments and mass-rooted religious organizations in strategic and sustainable projects is an important social force to guarantee the existence of gender awareness program at schools. Last but not least, this is plausibly strengthened by international agents which have prioritized their projects to collaborate with academics, local governments as well as schools such as DBE projects (USAID), IAPBE (AUSAID) and many others to assure that gender awareness is not separate from school curricula. These projects have made use of gender analysis to design gender policies. In short, gender awareness is not only supported by the government through out national and local policies but also reinvigorated by international donors.

The last argument which provokes people not to agree is that so far there has been no proof whether integrating gender awareness at school curriculum really works to reduce gender inequality. No conclusive effect has been accumulatively detected from researches in Indonesia. However, some studies conducted in other countries have shown interesting findings. A study conducted by ${ }^{16}$ indicates that the gender sensitivity program did influence participants' attitude toward gender roles and equitable treatment of males and females. This evaluation study involved 2,314 males aged 12-20 from four

\footnotetext{
${ }^{15}$ National Plan of Action, 2003

${ }^{16}$ Green et.al 2005
} 
governorates in Egypt. This survey has significantly proved (six of the 12 scales had alpha scores over 6.5) that the subjects more favorably viewed that family decision making, community service, people's involvement in political activities, and domestics affairs are shared responsibilities. It is further indicated that, after joining the program, the respondents' views that domestic violence done by a husband to his wife that was something culturally justified tended to dramatically decline. Similarly, the attitudes toward male-female interaction, female genital mutilation, and other gender-based violence are more positively shifted. Even though these findings were not obtained from an experimental research, the wide coverage, the involvement of a large number of research subjects, and carefully selected measurement scales have offered strong and convincing results which may be safely generalized to other countries.

Kiambuthi's study ${ }^{17}$ strengthens the previous research. This research was done in Northern Kenya and involved junior high school students to test whether implementing gender awareness curriculum could modify the students' perceptions toward some gender disparities. Taken as a whole, the effectiveness of the gender awareness program was significantly proved. Similarly, this study revealed that the respondents perceived their counterparts more positively and, more importantly, these students also urged that education had to be more prioritized. This definitely can be an effective bridge to reach gender equality, though sometimes it takes a longer time with longer effects.

\footnotetext{
${ }^{17}$ Kiambuthi, W, 1999, Increasing gender awareness in Northern Kenya through a video curriculum. www.digitalcommons.libraries.colombia.edu/dissertation/AAI9939511
} 
A 2003 Swedish study among the physicians follows a similar track. Based on the findings of this study, Risberg, Hamberg, and Johansson ${ }^{18}$ have shown that the 468 specialists under this study perceived gender awareness in different favors. Gender disparities were also detected, especially among male physicians. It was not comprehensively analyzed because the nature of research method and the research instrument use (questionnaires) did not successfully obtain the root of such disparities. However, it indicates the view of educated male towards gender equality issue. The important finding of this research, two out three physician teachers found the importance of gender awareness in clinical tutorials, is considered a promising issue which may be reflected on a more recognized effort to improve the quality of teaching learning interactions.

These three studies are unquestionably worth noting to support the implementation of gender awareness hidden curriculum at our schools. Considering a widely spread of serious problems originating from gender disparities, it is definitely crucial to do a strategic effort with long term effect, that is gender awareness program. To put it briefly, it is pertinent to implement a gender awareness program as a part of available subjects. The flexibility and practicality of this gender awareness hidden curriculum mean that it can be put in place soon.

\footnotetext{
${ }^{18}$ Risberg,G. Hamberg, K and Johansson,EE, 2003, Gender awareness among physicians-the effect of specialty and gender. A study of teachers at a Swedish medical school. www.pubmedcentral.nih.gov/articlerender.fegi?artid=280661
} 


\section{Recommendations}

In doing so, some recommendations are proposed. First, it is undeniably important that similar research should be done to derive more scientific and convincing effects of gender awareness in eliminating gender disparities at school, especially in Indonesia context. These empirical data can function as a subtle ground with a 'take it for granted' acceptance. Secondly, providing more materials to cope some very specific culturally bound issues also should be addressed to the right educational agents. A gender-based need analysis ought to be done as a preliminary step in order that truly gender-equitable materials can be provided. Thirdly, a sufficient teacher training, especially for females, must be supported as a gender-sensitive teacher alone can contribute a crucial determinant of realizing gender equality at school. Fourthly, the intensive and sustainable involvement of all school staff, parents, and other key persons of the society as well as media are unavoidably necessary. Gender awareness program at school does require consciousness-raising of other different institutions. These seem difficult to realize but we, all together, can make it true. 


\section{REFERENCES}

Abrahams, FF and Sommerkon, IN (undated), Promoting gender awareness in the classroom ; an example from Germany. www.waxmann.com/fs/abrahams.pdf\#search

Aikman, S, Untelhalter, E and Challender, C. 2005. The education MDGs: achieving gender equality through curriculum and pedagogy change, Gender and development vol.13 no.1 March

Green, CP, et. al., 2004, Promoting gender sensitivity among boys in Egypt. www.cedpa.org/content/publication/detail/847

Guerard, EB, 2005, Computer teachers learn gender awareness, eschool news online. www.eschoolnews.com/news

Hadley, E, 2001, eds. Sexual harassment in schools, Gender Policy Review, July. http://genderpolicy.tripod.com/backissues/July2001.html.

Indraswari, 2006, Gender Equality: Easy to Theorize Difficult to Apply, Opinion, The Jakarta Post, August 9

Kiambuthi, W, 1999, Increasing gender awareness in Northern Kenya through a video curriculum. www.digitalcommons.libraries.colombia.edu/dissertation/AAI9939511

Kirk, J, 2004, Promoting a gender-just peace : the roles of women teachers in peace building and reconstruction, Gender and DevelopmentI vol.12 no 3 November

Risberg,G. Hamberg, K and Johansson,EE, 2003, Gender awareness among physicians-the effect of specialty and gender. A study of teachers at a Swedish medical school. www.pubmedcentral.nih.gov/articlerender.fegi?artid=280661 
SDNP, (undated), Malawi gender concepts, origins and background, www.sndp.org.mw/gender/concepts.html

UNESCO, 2000, Education for All 2000 Assessment: Thematic studies (Girls Education)

UNESCO, 2003, National Plan of Action Indonesia's Education for All.

portal.unesco.org/education/en/evphp.URL_ID=22302\&URL_DO=DO_PRINTPAGE\& URL_SECTION=201.html-16k

UNIFEM, 2006, Facts and figures on VAW.

www.unifem.org/gender_issues/violence_against_women/facts_figures.php?page2 